\title{
Ethnic Politics in China
}

\author{
Xing Zhou ${ }^{1}$
}

Received: 10 February 2022 / Accepted: 11 February 2022 / Published online: 28 February 2022 (c) The Author(s) 2022

\begin{abstract}
The development of Ethnic Politics in China can date back to 80years ago. As of today, its disciplinary system and norms have been established in a systematic approach, and many significant academic achievements have been made. After having systematically reviewed the academic history of Frontier Politics originating in the 1940s and the Ethnic Politics in the late 1980s and early 1990s, this paper expounds on their respective backgrounds and the consciousness of the academic discipline based on the reality of a multi-ethnic country. The paper goes on by elaborating on the progress made in the disciplinary development of Chinese Ethnic Politics at the beginning of twenty-first century, and summarizing the major achievements made over the past 20 years. Finally, the paper points out that more than one research approach ("plurality") exists in the field of Ethnic Politics, indicating the respective academic significance of these approaches for the study of issues related to the Chinese ethnic politics.
\end{abstract}

Keywords Ethnic Politics · Frontier Politics · Ethnic Theory and Ethnic Policy · disciplinary development

\section{Introduction}

In 1978, when China entered a new era of comprehensive reform and opening up, nearly all branches of social sciences including "ethno-national studies" were faced with great challenges, which included: emancipation of mind, knowledge renewal

Xing Zhou

ft102067pg@jindai.jp

1 Faculty of Cross-Cultural and Japanese Studies, Kanagawa University, 4-5-3 Minatomiral,

Nishi-ku, Yokohama-shi, Kanagawa 220-8379, Japan 
or reconstruction, and the restoration and reconstruction of disciplinary systems. As China is a multi-ethnic country, this makes ethno-national studies a very important, unique, and broad academic field. It not only includes independent sub-branches such as Ethnic Theory and Ethnic Policy, ethnic history, ethnolinguistics, ethnic religious studies, ethnic economy, and ethnology, it is also closely related to practices in ethnic affairs such as the regional ethnic autonomy and ethnic policies. Over the past 40 years, the academic scope of ethno-national studies has been constantly expanding in China, with the contents becoming increasingly diversified and profound. Among the achievements in this field, the emergence or reconstruction of several new academic fields stand out. One of the most characteristic examples is the emergence and rapid development of Ethnic Politics as a relatively independent discipline. This paper focuses on the inception, emergence, and development of Ethnic Politics, with the objective of facilitating its sound development in the future in China. ${ }^{1}$

In recent years, there has been an upsurge among Chinese scholars in reviewing, sorting out, summarizing and analyzing the historical development of Ethnic Politics in China (Lu and Huang 2010; Yan and Jiang 2015; Qing 2016; Zhou and Ma 2018, etc.). This is a manifestation of their academic awareness of finding a development direction after Ethnic Politics was established as a discipline. There are subtle differences in the starting points of these reviews. Some of them emphasize the political foundations of the discipline, while others highlight ethnology. Certainly, some scholars pay more attention to the evolution or inheritable relationship between Ethnic Politics and the local Ethnic Theory long established in China. In any case, such reviews have all helped us to further consider the value and legitimacy of this discipline in China. However, they do contain imperfections. First of all, they are too entangled with the origin of the name or the term of "Ethnic Politics", but ignore the importance of Frontier Politics, which emerged in the 1940s in China. Second, they have all overlooked the process of disciplinary construction of Ethnic Politics from the late 1980 s to the early 1990 s. Zhou Xing believes it is necessary to clarify that this discipline originated from Frontier Politics in China. Meanwhile, as a witness and participant in the discipline's development during the 1980s and 1990s, Zhou Xing feels it is his responsibility to elaborate on this process through this paper. Therefore, the academic history of Ethnic Politics in this article dates back to the early 1940s, which is 80 years ago.

\section{Research methodology}

This paper summarizes the academic history of Ethnic Politics, covering its emergence, establishment, and development in China. The basic methodology adopted is literature review, namely gathering and citing the most direct, the most important, and the most representative fundamental documents related to this topic over the

\footnotetext{
1 This paper was written for the "International Conference on the Construction of Modern Nation-States and the Sense of Community for the Chinese Nation \& Symposium to Commemorate the 120th Birthday of Mr. Yang Kun” of the CASS Forum (2021).
} 
past century, and then interpreting and commenting on their background, contents, keywords, and their significance and contributions to the development of Chinese Ethnic Politics.

By comparing diachronic materials, this paper has identified several basic stages during which Ethnic Politics was presented and standardized. After that, by analyzing and examining the similarities, differences, and relevance of different stages and of different disciplinary norms, this paper clearly depicts the development course and direction of Ethnic Politics as a localized discipline in China.

\section{Results and discussion}

Building on the analysis of fundamental documents, as well as the statements of academic history on the development process of Ethnic Politics in China, the results of this study mainly confirm that Ethnic Politics in China is not a direct borrowed discipline from the West, but one constructed by native scholars in response to the need to resolve ethnic problems within the governance practices of multi-ethnic China. Therefore, it has always been a native discipline, localized to China.

In 1939, there was debate between Chinese intellectuals over whether the Chinese Nation was a "unified one" or one comprising "multiple ethnic groups". This debate was driven by the major challenges at that time, namely the external aggression and internal conflicts as well as the border crisis. This debate directly inspired Yang Chengzhi and Wu Wenzao's attempt to create "Frontier Politics Studies" or Frontier Politics. In particular, Wu Wenzao's conception of Frontier Politics, which combines the academic wisdom of both anthropology and politics, is rich in application, and can be regarded as the origin of Ethnic Politics in China. Since the 1950s, the research field of Ethnic Theory has gradually taken shape in China's mainland, which combines Marxist Ethnic Theory, the study of the $\mathrm{CPC}^{2}$ 's ethnic policy, and the study and summary of the practical experiences of the newly-established Chinese government in dealing with ethnic minority affairs. In the late 1970s, China entered an era of comprehensive reform and opening up and Ethnic Theory faced a series of topics such as ideological emancipation, knowledge renewal, and disciplinary transformation. Therefore, from the late 1980s to early 1990 s, there were attempts to bridge the gap between Frontier Politics and Ethnic Theory, to "de-ideologize" the accumulation of relevant knowledge of Ethnic Theory, and to construct the discipline system of "Political Ethnology" or Ethnic Politics on this basis. As one of the important developers of the Ethnic Politics discipline at this stage, Zhou Xing finished his doctoral thesis Essentials of Political Ethnology in 1989 and then published his work Ethnic Politics in 1993. About 10 years after the publication of Ethnic Politics, the constructive norms of Ethnic Politics in the book have been recognized by Chinese scholars from the fields of politics, ethnology and ethnic theory. At the beginning of the twenty-first century, political science has had a great impact on the disciplinary analysis of Ethnic Politics. Meanwhile, relevant domestic universities have successively opened courses on Ethnic Politics and set up doctoral and

${ }^{2}$ CPC: the Communist Party of China 
master's programs in this field. This means that Ethnic Politics, as a local discipline born in China, has been established and incorporated into the system of national social sciences.

After the three stages of Frontier Politics, Ethnic Theory, and "Ethnic Politics", "Ethnic Politics" in China has now reached maturity. It is not surprising at all to see that great importance has been attached to Ethnic Politics in China because it has provided the legitimate basis for China, as a multi-ethnic country, to devote itself to the construction of the "Chinese nation" and unity among all ethnic groups, and because it takes ethnic relations and ethnic affairs during this process as the basic research objects.

\section{Frontier politics following the trend of the times}

The 1911 Revolution led to the establishment of the Republic of China as a modern multi-ethnic state. After a series of trials and errors, the fundamental principle of "the Union of Five Ethnic Groups Under One Republic" was gradually established. In the first half of the twentieth century, however, China was faced with huge challenges brought about by external enemies and internal conflicts. Therefore, China had a number of urgent tasks: internally, to enhance national unity and the construction of the Chinese Nation; and externally, to fight against the imperialist aggression from abroad.

Before the establishment of the Republic of China, Liang Qichao had touched upon the concepts of a "Nation of China (Zhongguo Minzu)" and "Chinese Nation (Zhonghua Minzu)". His basic idea was to "unite all ethnic groups within the country" (Liang 1903) so as to integrate and build a modern state on the basis of the "Union of all Ethnic Groups in China". Based on a holistic perspective of Chinese history, he gained a broad picture of the emergence and history of the Chinese Nation, pointing out that "the Chinese Nation is actually formed by the integration of multiple ethnic groups" (Liang 1905), which has exerted a huge impact on later generations. Before and after the May Fourth Movement that took place in 1919, the concept of Chinese Nation, which takes all ethnic groups as a united whole, was gradually established because of the crisis caused by imperialism around China. The Japanese imperialist war of aggression against China and the separatist plot against China further deepened the nation's border crisis and worsened the existential threat faced by the Chinese Nation. At the same time, the common sense of national destiny shared by Chinese people of all ethnic groups has been unprecedentedly strengthened because of the common enemy of imperialism, which has contributed to the awakening of the Chinese nation as a whole, towards a national consciousness.

Against this backdrop, an academic debate over whether the Chinese Nation is a "unified one" or "multiple ethnic groups" took place among Chinese scholars in 1939 (Zhou and Zhang 2007). After the Japanese invaders set up a separatist regime through the puppet "Manchukuo" and occupied North China, the "Grand Thai Nationalism" coveted China's southwest frontier, which aroused the high vigilance of China's intellectual circles. In fact, Fu Sinian had touched upon this issue earlier, 
emphasizing that "the Chinese Nation is a united whole" (Fu 1935), which was not only a historical fact but also an existing reality. In 1939, Fu Sinian wrote a letter to $\mathrm{Gu}$ Jiegang to promote this debate, which reflected his strong sense of crisis. He believed that we should no longer distinguish single "Ethnic Groups" within the Chinese Nation and highlight their differences; academia should instead carry forward the concept of "the unified Chinese Nation" and prove that Han Chinese and ethnic minorities constitute a big family together. In response to Fu's appeal, Gu Jiegang wrote an article to emphasize that "the Chinese Nation is a united whole" (Gu 1939). He proved his argument by elaborating on the long history of China: although the concept of the Chinese Nation did not emerge until recent times, its existence has been an undeniable historical fact. Gu Jiegang pointed out that, ethnic groups such as Mongols, Tibetans, Miao people, and Dai people should be placed under the framework of the Chinese Nation.

Unlike the above-mentioned views which aim to promote the holistic development of the Chinese Nation from the country-level, some other opinions of anthropologists or ethnologists represented by $\mathrm{Wu}$ Wenzao and Fei Xiaotong have been made from the perspective of academic research. Wu Wenzao once advocated "cultural pluralism" and "political integration" (Wu 1939). Fei Xiaotong argued that states should not be equalized to cultures, languages, and races; to unite a country, we do not need to deny the fact that different cultures, languages, and races exist within the Chinese territory; to seek consensus on politics, we need to focus on eradicating political inequality rather than the boundaries of all ethnic groups. Fei wrote an article to analyze the concepts of state, nation, race, and clans. He believed that the solution to problems regarding ethnic groups was to allow "every segment constituting a country to enjoy equality". Wu Wenzao and Fei Xiaotong believed that China was a multi-ethnic country and the Chinese Nation should include the ethnic groups living at the southwestern border; studies on the ethnic groups living around the borders would not necessarily weaken the identity of the Chinese Nation, but was beneficial to the making of a country's ethnic policies (Fei 1939).

Such a discussion did not produce any clear conclusions at that time, nor did it polarize scholars on both sides. Instead, it resulted in a sound and healthy interaction and stimulation of thought. Since then, how best to deal with the relationship between "one" and "many" for multi-ethnic China has become a common topic for Chinese historians, ethnologists, and anthropologists, leading to more thought-provoking ideas among scholars. Half a century later, Fei Xiaotong delivered a famous speech titled "Unity of Pluralistic Society of the Chinese Nation" at Hong Kong Chinese University in 1988 (Fei 1989), which represented his lifelong studies on this issue.

It is fair to say that Fei Xiaotong's theory of "Unity of Pluralistic Society of the Chinese Nation" has become the most recognized consensus on this issue among Chinese historians, ethnologists, and anthropologists (Zhou 2010). His speech has not only supported his own argument as an anthropologist and ethnologist, but also reflected the wisdom and achievements of archaeologists and historians. He has partially accepted some other scholars' opinions including Gu Jiegang, and carefully thought about the academic approach of how to integrate opinions from both sides. He has also elaborated on the relations among multiple 
ethnic groups in China in a systematic manner, and thoroughly demonstrated the "Unity of Pluralistic Society of the Chinese Nation" from a holistic perspective on history. His theory has fundamentally transformed the theoretical pattern of Social Darwinism in the fields of ethnology and cultural anthropology in China, and facilitated the transition of ethno-national studies from the "five stages of social formation" to the theory of "interaction among all ethnic groups" and the "shared historical dynamic model of multi-ethnic groups" (Wang 2007).

The academic discussion in 1939 highlighted the most urgent task for China at that time, which was to make a choice between "building a Nation" and "building Ethnic Groups". This was a choice between sidestepping the constituent elements of the Chinese Nation - "ethnic groups" - to avoid forces with ulterior motives splitting China under the pretext of "National Self-determination", or recognizing differences, giving support to ethnic minorities and safeguarding sovereignty by promoting equality (Tan 2021). However, this was not a black-or-white choice; rather, we needed a theory that incorporated the two sides into a whole. "Ethnic Minorities" and the "Chinese Nation" should be a pair of concepts that go hand in hand. We should not emphasize one and neglect the other. I believe there was a dilemma of "time difference" during the discussion of 1939. Those scholars who insisted on the "one" did not overlook the "many"; however, due to the crucial situation at that time, they had to prioritize the integration of "one" so as to help strengthen and save the country. Those who emphasized the "many" certainly understood that a country needs national integration, and they knew more clearly how to better achieve that goal - it needed to be done on the basis of equality among all ethnic groups. However, it would take more time and could only be done when security and peace were achieved within this country.

Yang Chengzhi summarized the differences and connections between the opinions on both sides of the discussion. In Yang's article, he discussed the "classification and relations of national policies and ethno-national studies", and distinguished the "Ethnic Groups" in the field of ethno-national studies from the "Nation" in the field of national political power. His opinion can be concluded as follows: in a broad sense, the word "minzu" equals "nation" and "nationality"; while in a narrow sense, it refers to "ethnic group" or "ethnicity", which is different from the political meaning of the nation, or nation in a broad sense. In 1941, Yang Zhicheng published an article titled "Introduction to Frontier Politics Studies: ten basic terms and their meanings you should know first" (Yang 1941). In this article, he illustrated that ethnology should play a leading role in China's "Frontier Studies", but multi-disciplinary participation is also necessary. Yang Chengzhi had a clear understanding of the necessity of uniting all ethnic groups with political power in a sovereign state. He clearly indicated that this is the general trend followed by all countries in the twentieth century, and China is no exception (Yang 1942). "Nation" is a political term that needs to be integrated by the state. It is independent from but closely related to the natural "ethnicity". The construction of "nation" as political integration and ethnology as academic research can not only coexist but also be organically combined.

In 1942, Wu Wenzao published an article titled "Introduction to the study of frontier affairs", which became the foundation work for the construction of Frontier 
Politics (Wu 1942). At the end of 1940, Wu was appointed by the government of the Republic of China as a consultant in the advisory office, responsible for studying ethnic, religious and educational issues in the border areas. He also served as the executive director of "Association of Frontier Politics" (Lin et al. 1990). He was directly involved in frontier affairs, participated in the initiation of the "Association of Frontier Politics", and assisted in reviewing, writing and introducing manuscripts for the journal Public Forum on Frontier Politics. So naturally, he began to ponder over the disciplinary development of Frontier Politics. The concept of "Frontier Politics" came into being in China in earlier dynasties, and mainly referred to the governance of imperial courts in borderland areas through a wide range of approaches. At the end of the Qing dynasty and the beginning of the Republic of China, issues regarding Frontier Politics became a hot topic due to the crises facing the country. From the perspective of academic history, "Frontier Politics Studies" in its early stage mainly refers to the studies on the history and geography of border areas; Frontier Politics in its later stage, however, as conceived by Wu Wenzao, needed the participation of multiple disciplines. Therefore, Frontier Politics was preliminarily established during the Republic of China against the backdrop of uniting and mobilizing all ethnic groups to fight against foreign aggression. During the period of the Republic of China, Frontier Politics initially formed a border area study on a rich array of aspects, including the politics, history, geography, ethnic groups, cultures, and societies, which obviously has the attribute of multi-disciplinary cooperation (Wang 2014).

Frontier Politics is a localized effort by Chinese ethnologists during a specific historical context. For Wu Wenzao, the Sinicization of sociology and anthropology, community research, and Frontier Politics are closely related to each other. He emphasizes the importance of "field investigation" and "field study", and takes community research as the fundamental methodology of Frontier Politics. His arguments on Frontier Politics are quite convincing in terms of academic theory, attaching great importance to the applicability of ethnology and anthropology, as well as their combination with politics. He clearly pointed out that the viewpoints of Frontier Politics come from both politics and anthropology: "The Introduction to Frontier Politics is mainly based on anthropological points of view and supplemented by political points of view." Therefore, Frontier Politics focuses on anthropology and is supplemented by politics, and conducts a comprehensive analysis in combination with many social sciences, so as to study the "politics, facts, systems, and administration of ethnic groups in border areas". Wu Wenzao believed that, to study the politics in border areas, scholars have to study ethnic groups living there at the same time, which is also the underlying reason why Frontier Politics has to be discussed from the "anthropological aspect". As Frontier Politics can provide "references for frontier policies and improve the political system in border areas", he advocated "using Frontier Politics as the basis to lay a foundation for making new frontier policies and facilitate the implementation of these policies". Wu Wenzao argued that, Frontier Politics can help implement the promise of regional autonomy in China for all ethnic groups, as soon as the War of Resistance against Japanese Aggression is won, so that an emancipated and unified Chinese Nation will be formed and a multi-ethnic country will be established. This reflects the academic orientation of the Frontier 
Politics created by Wu Wenzao, which centers on the consensus of achieving equality and unity between all ethnic groups as well as the unification of the whole country. It also showcases that he tried to use his academic research to understand and transform the Chinese society and improve the political system of China, as well as his ideal of realizing unification of the country, well-ordered administration and scientific policy-making in border areas, and indiscriminate equality and unity of all ethnic groups in China.

It is fair to say that Wu Wenzao's "Introduction to the Study of Frontier Affairs" marks the birth of Ethnic Politics in China (Zhou 1997). Frontier Politics is actually a branch of political ethnology or Ethnic Politics. It is the earliest and relatively systematic record of the disciplinary system of political ethnology or Ethnic Politics throughout the history of ethnology and anthropology in China. Due to the regime change in 1949, the development of Frontier Politics in China's mainland was forced to stop. ${ }^{3}$

\section{From ethnic theory to ethnic politics}

After the 1950s, due to drastic political and social changes, sociology, anthropology and ethnology, including Frontier Politics, were neglected, rejected, and even canceled in China's mainland. These disciplines were replaced by Historical Materialism, Marx's Theory of Social Formation, and "Ethnic Theory and Ethnic Policy". The full name of "Ethnic Theory and Ethnic Policy" is "Marxist Ethnic Theory and Ethnic Policy of the Communist Party of China", which is usually referred to as Ethnic Theory for short under many circumstances. In the ethnic work of the newly found People's Republic of China and then in the relevant research in this regard, Ethnic Theory has soon occupied a crucial and guiding position.

During the Yan'an Period before the CPC established government (19351948), the Party had carried out special research on "ethnic affairs". After the founding of the People's Republic of China in 1949, the CPC made prompt efforts to organize and conduct more large-scale and in-depth surveys and research on "ethnic affairs", that is, the National Survey of Society and History of Chinese Ethnic Minorities (1956-1964). In the meanwhile, the CPC fully introduced Marxist Ethnic Theory, including Stalin's definition of ethnicity, Marx's Theory of Social Formation, ${ }^{4}$ and the Soviet School of Ethnology (Yang 1984), and strived to combine such theories with its work on domestic ethnic affairs.

\footnotetext{
${ }^{3}$ Frontier Politics continued to develop in Taiwan after 1949, and it came to a stop when the Graduate Institute of China Border Areas Studies of National Chengchi University was renamed as the Graduate Institute of Nationalities Studies in 1990. However, Chinese Frontier Politics was redefined and interpreted in China's mainland in the middle of twenty-first century. Please refer to: Wu Chuke, Chinese Frontier Politics, China Minzu University Press, 2005.

4 This is reflected in the grand survey of ethnic minorities' society and history, during which the "Primitive society survey outline", "Slave society survey outline", and "Feudal society survey outline" were formed respectively. Please refer to The Social and Historical Survey of Chinese Minorities (Part 2) Selected Documents edited by the Museum of Ethnic Cultures of Minzu University of China, Xueyuan Publishing House, 2018.
} 
As a result, the academic field of Ethnic Theory with Chinese characteristics has gradually taken shape.

Although many of the practitioners mentioned above who personally took part in the National Survey had realized that their work was closely related to ethnic politics, and should by nature belong to the discipline of "ethnic political science", they failed to contribute to any discussions on disciplinary development when ethnology and anthropology were criticized at that time. From the 1950s to the 1980s, when ethnology and anthropology were gradually included into "ethno-national studies (study on Minzu/ethnicity)", once again Ethnic Theory gradually possessed the special status of the leading field of ethno-national studies.

The field of Ethnic Theory has two characteristics. On the one hand, it contains the rich and valuable knowledge accumulated in Ethnic Theory research, ethnic policy research, and practices in handling ethnic affairs. To understand the ethnic issues and policies in China, we should start from this field. On the other hand, it synchronizes with the ideological Left-wing Views in China's society over the past decades, featuring many dogmatic factors. Therefore, many discourses in this field either simply reread the remarks of the classic Marxist writers, or interpreted the spirit of the instructions of the CPC and the state leaders' guiding principles on handling ethnic affairs.

Since the 1980s, China has entered a new era of comprehensive reform and opening up, people's minds have been further emancipated, and academic research has become increasingly active. Against such a backdrop, sociology and anthropology have returned to the centre-stage and have been rebuilt. Moreover, the academic fields related to ethno-national studies have all entered a new stage of discipline construction and comprehensive development. This is also true for Ethnic Theory. After the "Left-wing Views" were corrected, ethnic policies centered on regional ethnic autonomy were fully restored and implemented. New opportunities emerged for the development of Ethnic Theory. At that time, the most important topic for Ethnic Theory was to eradicate the negative effects of dogmatism and Left-wing Views, and to consider the relations of Ethnic Theory with other relevant academic fields. When it came to the late 1990s, problems in Ethnic Theory were further revealed and the discipline could hardly meet the requirements of handling ethnic affairs, as the government was devoted to fully building China into a modern multi-ethnic country. For example, Ethnic Theory over-emphasized the ethnicity definition of the "Four Commons (common geographic location, common language, common economic life, common culture/psychology)" in an essentialist way, which tends to believe that ethnic boundaries have been clear and fixed since ancient times (He 2019). In addition, it actually overemphasized the division and differentiation of the ethnic groups, which contributed to the solidification of the Chinese citizens' ethnic identity. The biggest problem in Ethnic Theory is that when talking about "ethnic affairs" in China, it focuses on ethnic minorities only and overlooks the majority - the Han Chinese. Moreover, it seldom touches upon other theoretical and practical issues of great significance such as the construction of "Nation" (the community of the Chinese Nation) and national identity.

On May 13-14, 1987, the Second Symposium of Young Ethnic Theorists was held in Beijing, which focused on demonstrating the status of Ethnic Theory as an 
independent discipline. At the meeting, Zhou Xing proposed the opinion that, if Ethnic Theory must be called an independent discipline, it might as well be positioned as "political ethnology or Ethnic Politics". Zhou Xing believed that, if Ethnic Theory could break the shackles of dogmatism and build on the community research conducted in different ethnic areas of China, it would surely become "political ethnology". Later on, Zhou Xing followed this direction to write his doctoral dissertation, trying to reintegrate and transform the knowledge of Ethnic Theory into "political ethnology" in a systematic manner. In his "Introduction to the Study of Frontier Politics", Wu Wenzao raised "two viewpoints", namely the "political point of view" and "anthropological point of view", which directly or indirectly affected Zhou Xing's basic conception of political ethnology. To this end, he wrote a special chapter "From Frontier Politics to Political Ethnology" in his dissertation. In this sense, Zhou Xing's development of political ethnology was inspired by and originated from Wu Wenzao's Frontier Politics.

The basic research problem to be solved in Zhou Xing's doctoral dissertation is to reconstruct Ethnic Theory into "Political Ethnology" on the basis of Chinese Ethnic Theory at that time and absorbing the academic wisdom of both Ethnology and political science, to conduct a preliminary and systematic demonstration of "political ethnology" being established as a discipline. Furthermore, the dissertation aims to identify the objects and topics of Political Ethnology, and to establish the statement framework for Chinese Political Ethnology, allowing is to cover the basic scope of Ethnic Theory, so as to greatly improve and bring sufficient attention to the theoretical views, knowledge, wisdom, and experiences of Chinese Ethnic Theory. Zhou Xing believes that the Ethnic Theory in the new era should keep pace with the times in a scientific manner, and "Political Ethnology" is a meaningful attempt in this respect (Zhou 1988, 1989).

From 1989 to 1992, Zhou Xing's point of view was transformed from Political Ethnology towards Ethnic Politics, and he tended to describe the disciplinary reconstruction of Ethnic Theory as Ethnic Politics. He made this change mainly for two reasons: first, it would be easier to accurately illustrate the knowledge contained in Ethnic Theory if it was expressed as Ethnic Politics; second, in the late 1980s and the mid-1990s, foreign books and essays on cultural anthropology and ethnology were translated into Chinese and introduced to China at a large scale, which would definitely lead to discussions on the relation between cultural anthropology and ethnology in China. Considering the academic atmosphere in China at that time, it was clear that the relation between Political Ethnology and Political Anthropology would be a topic impossible to avoid.

Influenced by the work of identifying ethnic minorities (1953-1965 and 1979) and the Soviet School of Ethnology, the Chinese ethnologists have gradually formed the habitual consciousness to conduct their research according to a certain ethnic division (Zhou 2008), which has helped form an intermingled relationship with ethno-national studies and Ethnic Theory. Since the 1990s, Chinese ethnologists have long reflected on the limitations posed by highlighting "Minzu/Ethnic Groups" while neglecting "cultures". In particular, the introduction of the "Ethnic Groups Theory" has relativized the definitions of "Ethnic Groups" in the fields of ethnonational studies and Ethnic Theory, making ethnology return to cultural studies or 
move towards social and cultural anthropology. Some senior ethnologists including Yang Kun argued that, "Political Ethnology" is "political anthropology" (Yang 1984). Zhou Xing used to include Western political anthropology among the academic resources which Chinese Political Ethnology can learn from and interact with, and listed "Ethnic Political Life" as a research subject of Political Ethnology. However, the Western political anthropology has a complicated background of colonialism, and has a knowledge genealogy unlike that of the Chinese Ethnic Theory. Given that Ethnic Theory is based on the political reality shared by all ethnic groups in China, it is necessary to deal with the complicated ethnic political issues that exist in multi-ethnic China. This makes is difficult to form a consistent relationship with the Western political anthropology. To avoid any confusion around the relationship between Political Anthropology and Political Ethnology in the new academic environment, Zhou Xing gradually tends to use the definition and expression of "Ethnic Politics". He has realized that illustrating Ethnic Politics from the perspective of political science is easier for the readers to understand, and will also facilitate the healthy dialogue with Ethnic Theory. Compared with "political ethnology", the expression of "Ethnic Politics" is more suitable for us to establish this discipline.

Ethnic Politics, which was extracted and adapted from my doctoral dissertation (Zhou 1993), was published in September 1993. As the first monograph in China on Ethnic Politics written in Chinese, it has received due attention and positive comments from academia and has been gradually acknowledged by fellow researchers. Some Minzu universities have used it as a textbook, and some teachers from other universities have also included it in the list of teaching materials for political anthropology or ethnology.

\section{The establishment and development of ethnic politics}

From 1987 to 2000, the disciplinary ideas and preliminary framework of Ethnic Politics were gradually accepted by Chinese academic circles. Some scholars of Ethnic Theory held a positive view on Ethnic Politics, deeming it constructive to the academic development of Ethnic Theory. Meanwhile, similar expressions and related research from the field of politics also stood out. Although many scholars did not use the term "ethnic politics" during this period, their research undoubtedly belonged to the category of Ethnic Politics, for example, research on the integration of the political rights of ethnic minorities into the democratic political system of modern states from the perspective of Mexican ethnic studies (Zhu 1994), research on ethnic processes and ethnic political processes (Wang 1997, 1998), research on inter-ethnic politics (Chen 1996), and research on the political culture of ethnic minorities (Zhou 1994). It is fair to say that these achievements are the major academic gains accumulated by Ethnic Politics in China.

After entering the twenty-first century, Ethnic Politics has gained strong support from the field of politics. After the reform and opening up in China, politics, together with sociology and ethnology, has seen great opportunities for growth, including the growth of various branches of politics. Ethnic Politics was introduced as a new subdiscipline of politics, which has been fairly logical since the very 
beginning. From the perspective of politics, Zhou Ping has made great contributions to the constructive demonstration of Ethnic Politics as a discipline. From 2000 to 2003, Zhou Ping published a series of monographs on Ethnic Politics (Zhou 2000, 2001, 2003a), which reflected his accumulation of knowledge in this field. In Introduction to Ethnic Politics (Zhou 2001) and Ethnic Politics (Zhou 2003a, b), Zhou Ping systematically analyzed the basic concepts, categories, and positions of Ethnic Politics, and holds that Ethnic Politics, from the perspective of politics, takes ethnic political life and ethnic political phenomena as the research targets. He comprehensively standardized the main dimensions of ethnic political life, while analyzing the generative mechanism and evolution of ethnic political issues, thus contributing to the constructive statement of the basic framework of Ethnic Politics. He also argued that the research target of Ethnic Politics, as a subdiscipline of politics, is the ethnic political life and ethnic political phenomena; and that the disciplinary basis of Ethnic Politics is rooted in the foundation of politics rather than ethnology. That is why it is called "Ethnic Politics" instead of "Political Ethnology" (Zhou 2003b).

Zhou Ping's expounding of Ethnic Politics has continuously strengthened the narrative from politics and the disciplinary position of politics. When his Ethnic Politics (Second Edition) (Zhou 2007) was published in 2007, it greatly supplemented or strengthened the content on ethnic political behavior and ethnic political evolution. Following his dissertation in 2003, after a gap of 16 years, Zhou Ping wrote another article to discuss the discipline development of Ethnic Politics, pointing out that Ethnic Politics, as an emerging discipline, originated from the study of ethnic political issues in China. He argued that Ethnic Politics, as an ethnic political knowledge system, resulted from the development of political science as a discipline in China since the reform and opening up, and that it was not only founded in China, but has also achieved great progress in China (Zhou 2019).

Meanwhile, it should be mentioned that during the period from 2001 to 2003, Zhu Lun published several crucial works on the theoretical research of Ethnic Politics $^{5}$ (Zhu 2001, 2002; Zhou 2003a, b). Zhu Lun's research on Ethnic Politics has a clear theoretical proposition. His "theory of jointnomy ${ }^{6}$ among the ethno-national communities" and profound insights on the relationship between autonomy and cogovernance, including his reflection on the Western classical ethnic political theory, can be regarded as a major outcome of China's study of ethnic politics. Zhu Lun's monograph Co-governance among the Ethnic-national Communities: A New Proposition on the Ethnic-National Politics is a high-level monograph on Ethnic Politics (Zhu 2012). He pointed out that there lacks a basic consensus on the concept of Minzu (民族) among Chinese scholars, as many of them translated the English terms "nation" and "nationality" in Western nationalist theory, "ethnos" and "ethnic group" in anthropology, and even "people" in history and politics into the same Chinese word Minzu (民族), which can also be understood as "multi-ethnic national community". This situation has not only affected international academic exchanges

\footnotetext{
5 Zhu Lun was then the head of the world Ethnic Study Department of the Institute of Ethnology and Anthropolgy, Chinese Academy of social sciences.

6 Corresponding to the word "autonomy", Zhu Lun created a new word: jointnomy, which has almost the same meaning as "co-governance".
} 
and often led to misunderstandings, but has also had a negative impact on the development of China's theoretical system of ethnic politics. After abstracting the Chinese word "Minzu", Zhu Lun translated it into "ethno-national community". He believed that, when dealing with ethnic issues, contemporary multi-ethnic countries must shake off the traditional "nation-state" and "ethnic autonomy" views, and discard the ideological opposition that tends to result in polarization between ethnic separatism and ethnic assimilation. He put forward a brand-new proposition of "cogovernance among the ethno-national communities" as a norm of ethnic political life in multi-ethnic countries, regarding it as a means of good governance for ethnic relations in multi-ethnic countries. In his view, this can help effectively ease the tension between ethnic politics of difference and national sovereignty, and also successfully resolve the conflict between safeguarding the individual rights of citizens and protecting national collective rights and interests.

In 2003, Minzu University of China independently offered a doctoral program in Ethnic Politics, while obtaining the right to grant a master's degree in this major. From the late twentieth century to the early twenty-first century, some scholars in the field of Ethnic Theory in this university began to accept the the nomenclature Ethnic Politics, and quickly established an academic team. Qing Jue is a representative scholar, who began ethnic politics studies with the educational background of Ethnic Theory, making great contributions to China's Ethnic Politics. Since 2013, Studies of Ethno-National Politics (Volume 1-5), issued under Qing Jue's general editorship, has been published, incorporating a large number of papers on Ethnic Politics to a high standard. The academic goal of the Studies of Ethno-National Politics is to make a continuous, comprehensive and in-depth observation and hold academic debate on the research targets, core issues and research methodology related to Ethnic Politics. In addition to demonstrating and explaining ethnic political appeals at different levels, it also aims to build a platform for dialogue between different ethnic political discourses, and strengthen academic autonomy and confidence in research on Ethnic Politics. In recent years, Qing Jue has published several papers on the discipline development of Ethnic Politics, drawing extensive attention among peers (Qing 2013, 2014, 2016). He argued that, since the 1990s, after more than 30years of exploration and development, China's Ethnic Politics has shaped a diversified research system based on politics and ethnology, and achieved fruitful results in the fields of multi-ethnic state theory, ethnic political development, ethnic political culture, ethnic political participation, inter-ethnic democracy, and cross-border ethnic groups. Qing Jue pointed out that, since China, as a multi-ethnic country, is in a critical period of social transformation, we should also explore new a path of ethnic politics research from the aspects of ethnic power and ethnic rights, ethnic political participation under the democratic framework, nationalism, and cross-border ethnic issues. Finally, we should build a disciplinary knowledge system with Chinese characteristics and theoretical significance for solving practical problems.

Based on the actual process of academic history mentioned above, Chinese Ethnic Politics is not so much derived from the internal construction of politics as from the discipline transformation of Ethnic Theory. Since the late 1990s, some universities in China have offered related courses of Ethnic Politics in the Department of Politics or the Department of Ethnology, especially in majors related to Ethnic 
Theory, which also shows the close relationship between Ethnic Politics and Ethnic Theory.

\section{Core research subjects of ethnic politics}

In addition to the contributions made by scholars from such higher education institutions as Yunnan University and Minzu University of China, the scholar group from the Institute of Ethnology and Anthropology, Chinese Academy of Social Sciences, ${ }^{7}$ has also focused on in-depth research on inter-ethnic politics since the 1990s, and later published a series of significant academic results in the field of Ethnic Politics during the twenty-first century (Wang 2004, 2011a, b; Wang et al. 2004; Chen and Zhou 2010; Yan 2011). Their studies feature broad academic vision and are full of academic rationality. In particular, they have conducted multi-dimensional analyses on different aspects of inter-ethnic relations and integration of inter-ethnic politics, which not only include the expansion of ethnic political theory, but also analyze and investigate inter-ethnicity politics in China and abroad. Thanks to their perseverance and efforts, the research subject of inter-ethnic politics has now been highly recognized by the academic fields of Ethnic Theory, politics and ethnology, making remarkable contributions to Chinese Ethnic Politics.

Great progress has been made in Ethnic Politics over the past 30 years. Not only have its research themes been progressively diversified, breakthroughs have also been made in the discipline's core issues. Its greatest contribution has been to demonstrate and promote the legitimacy of the "nation" (Chinese nation) building and national integration of multi-ethnic China. From the perspective of nation building in the modern state of the People's Republic of China, the discipline has made many attempts along the path to unite all ethnic groups to become the Chinese nation, gaining both experience and lessons. For example, there were obvious limitations in the research of Ethnic Theory field before the late 1980s. These studies basically did not involve the topic of the main ethnic group, nor did they explore the significance of national integration and the community of Chinese nation. These studies only focused on ethnic issues with regard to ethnic minorities. It was not until Fei Xiaotong put forward the theory of Unity of Pluralistic Society that the importance of building the community of the Chinese nation and unifying national identity in multi-ethnic China became the consensus of academia and the whole society. The direction of Fei's theory is quite clear, which is based on the basic reality that China is not only home to numerous "small traditions" of ethnic groups, local and folk cultures, but also has a more broad-based and shared "great tradition of history and culture". Therefore, we should actively promote national identity while taking into account cultural diversity at the same time.

In the dimension of establishing unity between all ethnic groups in China, that is, the Chinese Nation, Ethnic Politics takes the consciousness of a community of the Chinese nation and its construction as an important concern for observing and studying ethnic

\footnotetext{
7 Institute of Ethnology and Anthropology, Chinese Academy of Social Sciences (IEA, CASS): the key institution of China's ethno-national studies, formerly named The Institute of Ethnicity Studies prior to October, 2002.
} 
issues, and provides academic support and strong argumentation for the establishment of an institutional system and governance model that can effectively maintain the harmonious relations of all ethnic groups in a multi-ethnic country and can continuously enhance the national identity of all ethnic groups. The core research subject for Chinese Ethnic Politics is the relationship between the multi-ethnic country and ethnic groups, from the state's perspective, which means how to address inter-ethnic relationships and ethnic issues in a multi-ethnic society. Evidently, we must fully affirm the significance of the Chinese nation, which is composed of all citizens and supports the multi-ethnic country (Zhou 2019). In other words, the theoretical discussion of ethnic politics has remarkably changed the discourse system of the "state", "citizen" and "nation", which were long underappreciated and ignored in Chinese ethno-national studies.

In 2018, the "Chinese Nation" was officially written into the newly-revised Constitution, all of which signifies that multi-ethnic China needs to strengthen the political identity of all its citizens to the Chinese nation. For a long period of time, many people, misled by the nation-centered ethnic theory in Western countries, are prone to embrace biases against China's measures to implement national integration, smearing it by the accusation of ethnic assimilation. However, all multi-ethnic countries in the world are advancing national integration in the process of modernization, why shouldn't multi-ethnic China do the same thing? Therefore, Ethnic Politics bears a duty to clearly explain its principles in this respect, especially regarding ethnic political theories in multi-ethnic countries, which are different from the theory of the nation-states. This will by no means encroach on the political, social and cultural interests and rights of different ethnicities, ethnic minorities in particular. Instead, it is exactly what Ethnic Politics has long been striving for to develop a sound relationship between national integration, "nation" building and the participation of ethinc minorities in social and political affairs.

Academic research focusing on Chinese Ethnic Policies, with its grounding in the basic facts of ethnic relationships in multi-ethnic China, has occupied a predominant position within the existing academic achievements of Ethnic Politics. The finetuning and improvement of Chinese ethnic policies in the new era have become the focal point of Ethnic Politics (Luo and Xu 1999; Li 2009; Peng and Li 2014; Pan 2016). Although many disputes do exist due to different standpoints, perspectives and methodologies, in-depth discussion from the perspective of Ethnic Politics has gradually become the mainstream of academic circles in China.

\section{Conclusion}

Some scholars believe that, from the perspective of the discipline's source, Chinese Ethnic Politics was introduced from the West, as it was originally the result of research by European and American scholars on international migrants (Zhu 2012). However, in terms of the origin and development of the discipline in China, it was not a borrowed discipline from any other countries, but a native, self-contained field of knowledge born in China. We can say that politics and ethnology were both introduced from other countries, but not Frontier Politics, because it was actually conceived by Wu Wenzao. We can also say that Marxist 
Ethnic Theory was borrowed from other countries, but not China's Ethnic Policies, because they were gradually established during the social reform and development process of China's multi-ethnic society. In the late 1980s and early 1990s, although referring to some relevant foreign knowledge and information, Zhou Xing's conception and disciplinary design of political ethnology and Ethnic Politics were definitely not simply the introduction of Western ethnic politics, but mainly based on China's existing Ethnic Theory. In other words, Zhou Xing based his studies on the Chinese experience of governing a multi-ethnic country, and the academic achievements made by Chinese scholars over the years in Ethnic Politics and Ethnic Policies.

Ethnic Politics in China is a product "created" by native scholars (Lu and Huang 2010). When Zhou Xing conceived of this concept, he knew about the existence of Political Anthropology in the West, and tried to acculturate it to "Political Ethnology". However, the disciplinary development finally moved towards Ethnic Politics, which bears little relation to Western Political Anthropology. At the beginning of the twenty-first century, some political scientists also made arguments around Ethnic Politics. Except for some terms borrowed from political science, the disciplinary framework and structural system were basically created by Chinese scholars. Hence, it is appropriate to ascribe Ethnic Politics with a Chinese academic genealogy, which is based on the practices of handling ethnic affairs in the multi-ethnic country of China, and has been established as a discipline on the basis of Chinese native scholars' creativity and development (Qing 2013).

Some scholars have written articles on the three approaches to understanding Chinese Ethnic Politics, namely the approach of politics, the approach of ethnology, and the approach of local Ethnic Theory (Yan and Jiang 2015). This point of view has urged us to consider the possibility that Chinese Ethnic Politics may, and can, take more than one form. On the basis of acknowledging that Ethnic Politics in China has received more powerful arguments from politics, and Ethnic Politics in China is a branch of "political science" focused on ethnic phenomena, it may be meaningful to probe into the possibilities of Ethnic Politics.

From the perspective of political science, Ethnic Politics was established as a branch of politics by using the conceptual tools, research methods and paradigms of politics to focus on political phenomena among ethnic groups, as well as the political attributes of ethnic relations and affairs - which is completely appropriate, since Ethnic Politics has been regarded as a new academic point of growth that is full of vitality in Chinese political science (Wang 2011a, b). However, when we take its process of formation into consideration, many will hold different opinions on whether Ethnic Politics should be interpreted as only an internal branch of politics. Gao Yongjiu positions his Overview on Ethnic Politics (Gao et al. 2008) as a basic course on an Ethnology major, meaning that Ethnic Politics constitutes an essential part of the disciplinary system of ethnology.

In fact, some scholars also view Ethnic Politics as a branch discipline of ethnology. They believe that it was produced during the development of ethnology with Chinese characteristics. In other words, they tend to interpret the viewpoints of Ethnic Politics from the perspective of ethnology (Zhou and Ma 2018). For a long time, ethnology or anthropology (especially Political Anthropology) has 
contributed greatly to the discussion of "ethnic political life", the political systems of different ethnic groups, ethnic group politics, nationalism, and other related issues. The above-mentioned major academic achievements relating to the building of the nation of the multi-ethnic China (the Chinese Nation) can exemplify how contributions from ethno-national studies, anthropology, and historiography are on a par with those from politics. Needless to say, anthropology or political anthropology have their own characteristics with regard to studies on ethnic political life, the identities of ethnic groups, nationalism, and other related issues, but neither is sufficient to fulfill the disciplinary goals of Ethnic Politics. Therefore, while acknowledging that ethnology is one of the major approaches, Zhou Xing agrees that "Ethnic Politics" is more suitable than "Political Ethnology" for the name of this discipline. In addition to the different approaches and the different disciplinary backgrounds, the name of this sub-discipline has not yet been unified. Some scholars use "Chinese Ethnic Theory and political studies", "ethnic development politics" (Yu and Yu 2008), or "Chinese Frontier Politics" (Wu 2008). Obviously, it is necessary for us to recognize the existence of "plural" Ethnic Politics and maintain the openness of Chinese Ethnic Politics.

Established during the reform and opening up, Chinese Ethnic Politics has been deeply rooted in the ethnic political life of multi-ethnic China and the many practices used in implementing policies to handle different kinds of ethnic affairs. Building on the substantial academic achievements that have been made over the past century, Ethnic Politics can not only provide interpretations and solutions for a range of ethnic phenomena and issues that have emerged in multi-ethnic China, this discipline can also contribute to the exchanges and dialogue with Western ethnic politics on an equal footing. On the one hand, it is important to vigorously promote the theoretical development of Ethnic Politics with China's unique characteristics as a multi-ethnic country. On the other hand, we should base our studies on China's realities and conduct research on the related ethnic affairs of other countries. While learning from the valuable academic achievements made by foreign scholars, we should also make our own theoretical contributions, which can be universally interpreted and applied for human society. This is precisely what Ethnic Politics should aim to achieve in China as a discipline.

Acknowledgements Thanks to the translators.

Author's contributions Xing Zhou completes all writing. The author(s) read and approved the final manuscript.

Funding Not applicable.

Availability of data and materials Not applicable.

\section{Declarations}

Ethics approval and consent to participate Not applicable.

Consent for publication Not applicable. 
Competing interests I have no any competing interests.

Open Access This article is licensed under a Creative Commons Attribution 4.0 International License, which permits use, sharing, adaptation, distribution and reproduction in any medium or format, as long as you give appropriate credit to the original author(s) and the source, provide a link to the Creative Commons licence, and indicate if changes were made. The images or other third party material in this article are included in the article's Creative Commons licence, unless indicated otherwise in a credit line to the material. If material is not included in the article's Creative Commons licence and your intended use is not permitted by statutory regulation or exceeds the permitted use, you will need to obtain permission directly from the copyright holder. To view a copy of this licence, visit http://creativecommons.org/licen ses/by/4.0/.

\section{References}

Chen, Jianyue (陈建樾). 1996. “族际沟通与民族主义一一族际政治的一种分析框架” (Inter-ethnic communication and nationalism: An analysis framework of inter-ethnic politics). 世界民族 (Journal of World Peoples Studies):(1).

Chen, Jianyue, Jinghong Zhou (eds.) (陈建樾、周竞红). 2010. 族际政治在多民族国家的理论与实践 (The Theory and Practice of Inter-ethnic Politics in Multi-ethnic Countries). Beijing: Social Sciences Academic Press (社会科学文献出版社).

Fei, Xiaotong (费孝通). 1939. “关于民族问题的讨论” (Discussions on ethnic affairs). 㿽世报·边疆周 刊 (Weekly on Frontiers of Yishi Newspaper) 1 May 1939 (19).

Fei, Xiaotong (费孝通). 1989. “中华民族的多元一体格局” (The pattern of diversity in unity of the Chinese Nation). 北京大学学报 (Journal of Peking University) (4).

Fu, Sinian (傅斯年). 1935. “中华民族是整个的” (The Chinese Nation is a united whole). 独立评论 (Independent Review) 15 December 1935 (181).

Gao, Yongjiu, et al. ed. (高永久等编). 2008. 民族政治学概论 (Overview of Ethnic Politics). Tianjin: Nankai University Press (南开大学出版社).

Gu, Jiegang (顾颉刚). 1939. “中华民族是一个” (The Chinese Nation is a united whole). Weekly on Frontiers of Yishi Newspaper (㿽世报·边疆周刊) 13 February 1939 (9).

He, Ming (何明). 2019. “民族研究认识论转向与民族学知识体系重构” (The turn of ethnological research epistemology and reconstruction of ethnological knowledge system). Thinking (思想战 线) (6).

Li, Fuqiang (李富强). 2009. “对中国民族政策“反思”的反思” (Reflection on 'reflection’ of China’s Ethnic Policy). 桂海论丛 (GuiHai Tribune) (2).

Liang, Qichao (梁启超). 1903. “政治学大家伯伦知理之学说” (The theory of Bluntchli Johann Caspar, a great political scientist). Xinmin Newspaper (新民从报) October 1903: 38-29.

Liang, Qichao (梁启超). 1905. “历史上中国民族之观察” (Observation of the Chinese ethnicities in history). Xinmin Newspaper (新民从丛报), March to April 1905: 65-66.

Lin, Yaohua, Yongling Chen, Qingren Wang (林耀华、陈永龄、王庆仁). 1990. “吴文藻传略” (Biography of Wu Wenzao), 吴文藻人类学社会学㸴究文集 (Selected Works of Wu Wenzao's Anthropological and Sociological Studies). Beijing: The Ethnic Publishing House (民族出版社).

Lu, Haifa, Sha Huang (陆海发、黄沙). 2010. “近年来我国民族政治学硏究综述(上、下)” (A summary of the research on Ethnic Politics in China in recent years. Journal of Yunnan Administration College (云南行政学院学报) (1 \& 2) ): 4-5.

Luo, Shujie, Jishun Xu (罗树杰、徐继舜). 1999. “世纪之交中国民族政策调整的思考” (Reflections on the adjustment of China's Ethnic Policy at the turn of the century). Journal of Guangxi University for Nationalities (广西民族学院学报) (2).

Pan, Chuanbiao (潘传表). 2016. “论民族身份的“非法律化”一反思我国基于民族身份的民族政策” (On the 'non-legalization' of national identity: rethinking China's national policy based on national identity). ECUPL Journal (华东政法大学学报): (1).

Peng, Qian, Cong Li (彭谦、李聪). 2014. “第二代民族政策”说的民族政治学考察” (An ethnic political investigation on the theory of "the second-generation Ethnic Policy”). Minzu Tribune (民族论 坛) (5). 
Qing, Jue (青觉). 2013. “如何认识民族政治学学科的发展” (How to understand the development of Ethnic Politics as a discipline). Heilongjiang National Series (黑龙江民族丛刊) (5).

Qing, Jue (青觉). 2014. “中国民族政治学砶究的新路径” (The new path of the study of China's Ethnic Politics). Heilongjiang National Series (黑龙江民族丛刊) (6).

Qing, Jue (青觉). 2016. “回顾与展望:中国民族政治学研究述评” (Retrospect and prospect: a review of the Study on Chinese Ethnic Politics). Journal of Minzu University of China (中央民族大学学 报) (1).

Tan, Tongxue (谭同学). 2021. “迈向主权的民族理论自觉一一围绕西南民族㸴究的三场分歧及其方 法论反思” (Ethnic theoretical consciousness towards sovereignty: three disagreements and methodological reflection on southwest ethnic studies). Open Times (开放时代) (2).

Wang, Hongliang (汪洪亮). 2014. “民国时期的边政与边政学(1931-1948)” (Frontier Political System and Frontier Politics in the Republic of China (1931-1948)). Beijing: People's Publishing House ( 人民出版社).

Wang, Jian'e (王建娥). 2004. “现代民族国家中的族际政治” (Inter-ethno-national politics in modern nation-state). Journal of World Peoples Studies (世界民族) (4).

Wang, Jian'e (王建娥). 2011a. “族际政治:20世纪的理论与实践” (Ethnic Politics: Theories and Practices in the 20th Century). Beijing: Social Sciences Academic Press (China) (社会科学文献 出版社).

Wang, Jian'e, Jianyue Chen, et al. (王建娥、陈建樾等). 2004. “族际政治与现代民族国家” (Interethno-national politics and nation-state). Beijing: Social Sciences Academic Press (China) (社会 科学文献出版社).

Wang, Jianxin (王建新). 2007. “宗教文化類型論の可能性一一中国民族学・人類学における民族硎究 の理論モデル再考” (Possibility for the theory of religious culture type: rethinking about the theoretical model of ethnic studies of Chinese ethnology and cultural anthropology). Interdisciplinary Cultural Studies (超域文化科学紀要) November (12).

Wang, Puqu (王浦劬主编). ed. 2011b. “中国政治学学术发展回顾与规划 (2006-2015)” (Review and planning of the academic development of Chinese political science (2006-2015)). Tianjin: Tianjin People's Publishing House (天津人民出版社) 389.

Wang, Xi'en (王希恩). 1997. “论前国家社会的民族政治过程” (On the ethnic political process of the pre-state society). Journal of World Peoples Studies (世界民族) (2): 10-17.

Wang, Xi’en (王希恩). 1998. “民族过程与国家” (Ethnic process and state). Gansu People’s Publishing House (甘肃人民出版社).

$\mathrm{Wu}$, Chuke (吴楚克). 2008. “试论中国边疆政治学与边政学、民族学的关系” (On the relationship between China's Frontier Political Science and Frontier Politics and Ethnology). Journal of Yunnan Normal University (云南师范大学学报): (4).

Wu, Wenzao (吴文藻). 1939. “论边疆教” (On education in border areas). Weekly Reviews of Yishi Newspaper (賹世报·星期论评), 5 March 1939.

Wu, Wenzao (吴文藻). 1942. “边政学发凡” (The introduction to Frontier Politics). Frontier Affairs (边 政公论) January. 1:5-6.

Yan, Qing (严庆). 2011. “㞲突与整合:民族政治关系模式研究” (Conflicts and integration: studies on modes of ethnic political relations). Beijing: Social Sciences Academic Press (China) (社会科学文 献出版社).

Yan, Qing, Shurong Jiang (严庆、姜术容). 2015. “当代中国民族政治学发展述评” (Review on the development of contemporary Chinese ethnic politics). Ethno-national Studies (民族硎究) (5).

Yang, Chengzhi (杨成志). 1941. “边政研究导论一一个应先认识的基本名词与意义” (Introduction to the Frontier Politics studies: ten basic nouns you should know first and their meanings). Guangdong Politics (广东政治) September 1941 (1).

Yang, Chengzhi (杨成志). 1942. “民族学与民族主义” (Ethnology and nationalism). Ethnic Cultures ( 民族文化) 2:8-9.

Yang, Kun (杨勂). 1984. “民族学概论” (Overview of Ethnology). China Social Sciences Press (中国社 会科学出版社).

Yu, Chunyang, Chunjiang Yu (于春洋、于春江). 2008. “民族发展政治学何以可能” (Why is development politics possible). Ludong University Journal (鲁东大学学报) (6).

Zhou, Chuanbin, Wenkui Ma (周传斌、马文奎). 2018. “中国民族政治学的回顾与前瞻” (Review and prospect of Chinese Ethnic Politics). Ningxia Social Sciences (宁夏社会科学) (5).

Zhou, Ping (周平). 1994. “少数民族政治文化论” (On the political culture of ethnic minorities). Social Sciences in Yunnan (云南社会科学) (5). 
Zhou, Ping (周平). 2000. “中国少数民族政治分析” (Political analysis on Chinese ethnic minorities). Yunnan University Press (云南大学出版社).

Zhou, Ping (周平). 2001. “民族政治学导论” (Introduction to Ethnic Politics). China Social Sciences Press (中国社会科学出版社).

Zhou, Ping (周平). 2003a. “民族政治学” (Ethnic Politics). Higher Education Press (高等教育出版社).

Zhou，Ping (周本). 2003b. “民族政治学: 研究对象、性质、特点及发展” (Ethnic Politics: research objects, nature, characteristics, and development). CASS Journal of Political Science (政治学硎究) (2).

Zhou, Ping (周平). 2007. “民族政治学(第二版)” (Ethnic Politics (second edition)). Beijing: Higher Education Press (高等教育出版社).

Zhou, Ping (周平). 2019. “民族政治学知识体系的构建、特点及取向” (The construction, characteristics, and orientation of the knowledge system of Ethnic Politics). CASS Journal of Political Science (政治学砶究) (1)

Zhou, Wenjiu, Jinpeng Zhang (周文玖、张锦鹏). 2007. “关于“中华民族是一个学术论辩的考察” (Investigation on the academic debate of 'the Chinese Nation is a united whole'). Ethno-national Studies (民族砶究) (2).

Zhou, Xing (周星). 1988. “试论政治民族学” (On Political Ethnology). New Horizons from TianFu (天 府新论) (5).

Zhou, Xing (周星). 1989. “谈谈政治民族学” (On Political Ethnology). Inner Mongolia Social Sciences (内蒙古社会科学) (1).

Zhou, Xing (周星). 1993. Ethnic Politics. China Social Sciences Press (中国社会科学出版社).

Zhou, Xing (周星). 1997. “边政学”的再思考” (Rethinking of Frontier Politics). Collected Works in Memory of Wu Wenzao (吴文藻纪念文集), Wang Qingren, Ma Qicheng, Bai Zhensheng (王庆 仁、马启成、白振声主编), ed. China Minzu University Press (中央民族大学出版社).

Zhou, Xing. 2008. Fundamental Problems Currently Facing Cultural Studies in Chinese Ethnology, Shinichi Kawai (ed.); New Challenges and Perspectives of Modern Chinese Studies. Tokyo: Universal Academy Press, Inc. 247-264.

Zhou, Xing (周星). 2010. “费孝通先生的民族理论” (Fei Xiaotong's Ethnic Theory). Journal of Art College of Inner Mongolia University (内蒙古大学艺术学院学报) (2).

Zhu, Lun (朱伦). 1994. “保障少数民族的政治权利是民主政治制度建设的重要课题” (Safeguarding the political rights of ethnic minorities is an important topic in the construction of democratic political system). Journal of Latin American Studies (拉丁美洲硎究) (2).

Zhu, Lun (朱伦). 2001. “民族共治论一一对当代多民族国家族际政治事实的认识” (The theory of ethnic co-governance: understanding of the inter-ethnic political facts in contemporary multi-ethnic countries). Social Sciences in China (中国社会科学) (4).

Zhu, Lun (朱伦). 2002. “论民族共治的理论基础与基本原理” (Ethno-National Jointnomy: Its Theoretical Basis and Fundamental Principles). Ethno-national Studies (民族硎究) (2).

Zhu, Lun (朱伦). 2012. “民族共治:民族政治学的新命题” (Co-governance among the ethnic-national communities: A new proposition on the ethnic-national politics). China Social Sciences Press (中国 社会科学出版社) 2 .

\section{Comments}

Publisher's Note Springer Nature remains neutral with regard to jurisdictional claims in published maps and institutional affiliations. 